\title{
THE IDENTIFICATION OF THE RESISTANCE LEVELS OF FUSARIUM OXYSPORUM F. SP. RADICIS - LYCOPERSICI AND TOMATO YELLOW LEAF CURL VIRUSES IN DIFFERENT TOMATO GENOTYPES WITH TRADITIONAL AND MOLECULAR METHODS
}

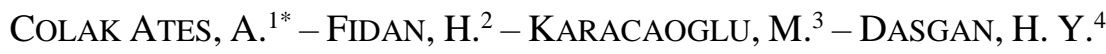 \\ ${ }^{1}$ Biological Control Research Institute, Department of Phytopathology, Adana, Turkey \\ ${ }^{2}$ Akdeniz University Agricultural Faculty, Department of Plant Protection, Antalya, Turkey \\ ${ }^{3}$ İnönü University Agricultural Faculty, Department of Plant Protection, Malatya, Turkey \\ ${ }^{4}$ Çukurova Univesity Agricultural Faculty, Department of Horticulture, Adana, Turkey \\ *Corresponding author \\ e-mail: aysegulcolak@hotmail.com; phone: +90-322-344-1784
}

(Received $14^{\text {th }}$ Nov 2018; accepted $16^{\text {th }}$ Jan 2019)

\begin{abstract}
Fusarium oxysporum f. sp. radicis-lycopersici (FORL) causes Fusarium crown and root-rot diseases and Tomato yellow leaf curling virus (TYLCV, Israel, Mild, Sardinian strains) infection leads to low yield and poor quality fruits, which causes important economic losses in tomato growing areas. In this study, previously developed molecular markers for FORL and TYLCV were used with 418 tomato genotypes which have characteristics of high yield, quality fruit and resistance to abiotic stresses. 62 tomato lines were obtained from Cukurova University (CU), 196 and 160 of tomato lines were generated from Western Mediterranean Agricultural Research Institute (BATEM) and private sector, respectively. All genotypes were tested with classical and molecular methods where species specific resistance RAPD and SCAR Frl primers for FORL, CAPS and Co-dominant SCAR primers for TYLCV resistance were used. Analyses revealed that 102 tomato genotype are resistant to FORL, 46 and 35 of plant genotypes contain TY3 and TY1 loci respectively. Three genotypes from BATEM and 4 genotypes from private sector contained the 3 target genes (FORL+TY1+TY3), however, none of the tested CU tomato genotype was resistant to the 3 target genes. Furthermore, yield and some fruit quality characteristics of 7 tomato lines which were resistant to both diseases were determined in molecular and classical tests.

Keywords: Fusarium crown and root-rot, marker assisted selection, PCR, Tomato yellow leaf curl virus, tomato
\end{abstract}

\section{Introduction}

It is extremely difficult to control the most significant form of Fusarium crown and root-rot disease (Fusarium oxysporum f. sp. radicis-lycopersici / FORL) that economically limits greenhouse tomato production since it is a soil borne disease (Colak and Bicici, 2011). FORL leads to recurrent infections during the season due to the spread of microconidia, especially in greenhouses, and results crop losses up to $90 \%$ in greenhouse tomato cultivation (Hibar, 2002). Commercially viable, agent-resistant indigenous varieties with adequate resistance to Fusarium crown and root-rot induced by FORL are not yet developed (Ozbay et al., 2004). In a study conducted in greenhouse tomato fields in Adana and Mersin provinces, formae specialis and strains of 87 Fusarium oxysporum isolates were determined in different locations and $60 \%$ of the isolates were identified as FORL while $40 \%$ isolate were identified as FOL. The 
results of this study demonstrated that FORL disease spreads rapidly in the region (Çolak and Biçici, 2013).

Tomato yellow leaf curl virus (TYLCV) is one of the most common diseases in greenhouse tomato fields for the last 20 years. Similar to other viral diseases, TYLCV is the most devastating virus disease active on tomatoes that can cause an $80-100 \%$ loss in tomato yields through epidemics in several countries and there are no chemical control agents against the disease which exhibits genetic differences similar to all virus diseases. It was first reported in 1964 on tomato plants (Moriones and Navas, 2000). TYLCV is persistently transported by silver leaf whitefly (Bemisia tabaci, Biotype B and Q). TYLCV has a quite broad host range. TYLCV is not mechanically transported and there are no records of transport via seeds (Czosnek, 2007; Mabvakure et al., 2016). Different TYLCV strains were reported at different parts of the world. The most common of these strains is the Tomato yellow leaf curl virus- Israel (TYLCV - IL), Israel strain. It is followed by Tomato yellow leaf curl virus- Sicily (TYLCSV - Sic), Tomato yellow leaf curl virus- Mild (TYLCV - Mld) and Sardinia (TYLCV - Sa) strains (Anfoka et al., 2005; Belabess et al., 2015). A study was conducted to identify the TYLCV strains present in Turkey in tomato cultivation fields in Antalya, Mersin and Adana provinces. The study determined that TYLCV-IL, TYLCV-Sa, TYLCV-Mld strains were present. It was observed that $93 \%$ of the whitefly samples collected on the infected tomato plants were B tabaci Biotype - B (B. argentifolii) and sample of 7\% were Biotype - Q (Fidan et al., 2011; Torre et al., 2018).

Parallel to the international studies, the use of resistant varieties in the control of plant diseases is the preferred method in Turkey to reduce the negative effects of the use of chemicals in the control of plant diseases. The development of resistant varieties in breeding work is obtained as a result of long-term studies. Several resistance genes, expected in a variety in breeding studies, could result in undesirable properties along with desirable ones (Scott, 2005). The morphological determinants used in traditional breeding studies could be affected by environmental conditions, although they help distinguish the genotypes. Homozygous, dominant and heterozygous individuals cannot be identified if any one of these characters is recessive. In recent years, molecular marker assisted selection (MAS) in disease resistance has been developing rapidly (Yan et al., 2017). Thus, hundreds of plants can be selected concurrently, reliably, and rapidly, by saving time and space in the selection of disease-resistant varieties (Darling and Brickell, 1994; Barone et al., 2005; Devran et al., 2018).

The FORL-related genetic resistance is controlled by a single ( $F r l$ gene) dominant gene (Roberts et al., 2001). Studies on identification of a marker associated with $\mathrm{Frl}$ demonstrated that $\mathrm{Frl}$ is located on the ninth chromosome in the tomato (Vakalounakis et al., 1997). In the study where the connections between RAPD-DNA markers and Frl were determined, 1000 different RAPD primers were tested for sensitive and resistant tomato lines. In the study, $\mathrm{Frl}$ gene connection distances were examined and it was determined that the UBC 194 was the closest primer with $5.1 \mathrm{cM}$. The selection of the closest primer in breeding studies is important for the reliability of the results. Since CAPS, SCAR and Co-dominant SCAR primers, which are a further stage of RAPD primers in the identification of FORL resistance, were not developed for this disease or were not patented and published, UBC 194-RAPD primer is used by several researchers (Fazio et al., 1999). 
Transferring the resistance in wild varieties to culture plants is one of the frequently used methods for TYLCV resistance. For this purpose, variety breeding was conducted with TY1 resistance marker developed with Solanum chilense (LA1969). However, it was determined that varieties with this resistance gene do not provide the desired level of protection (Castro et al., 2007). In most Mediterranean countries, TYLCV-Israel and Mild strains are common, and TYLCV Sardinia and Sicilian strains can also be found (Fidan et al., 2011). To ensure resistance against all these strains, it was reported that tomato lines that contain both Ty3 marker, developed from Solanum chilense (LA1932), and Ty1 gene provide significant resistance. Similar to all viral diseases, developing resistant varieties against this viral disease, which cannot be controlled chemically and possesses high genetic variability, became one of the most important strategies in recent years (Jensen et al., 2007).

The present study aimed to identify and validate the resistance against Fusarium crown and root-rot (FORL) disease and Tomato yellow leaf curl virus (TYLCV / Israel, Mild and Sardinia strains (TY1 + TY3 gene) that are significant problems in tomato cultivation with molecular and classical (symptomatologic) methods. For this purpose, 418 tomato lines, which were determined to be superior in terms of yield and certain fruit quality properties and determined to be resistant to abiotic factors, were used. Thus, yield and certain fruit quality properties of line and/or variety candidates that are resistant to both diseases (FORL + TY1 + TY3) were determined.

\section{Materials and methods}

\section{Plant material}

The main material included $418 \mathrm{~F}_{2}$ generation tomato lines procured from Cukurova University (CU, 62 lines), West Mediterranean Agricultural Research Institute (BATEM, 160 lines) and private sector (AYER, 196 lines). Fla.7781, Solanum chilense LA2779, Tayfun F1 and sensitive variety Hazera 5656 were used as positive controls in molecular and classical tests (symptomatologic) conducted to determine FORL and TYLCV resistance (Colak and Bicici, 2011; Kabaş et al., 2012).

\section{Molecular Studies}

\section{Genomic DNA isolation and amplification studies}

DNA Prufication Mini Kit (Thermo Scientific GeneJET Plant - K0792) was used in total genomic DNA isolation of tomato lines. For this purpose, $100 \mathrm{mg}$ young leaves obtained from positive controls and tomato line during the 2-4-leaf period. The DNAs were adjusted to $40 \mathrm{ng}$ using a spectrophotometer, and controlled in $0.8 \%$ agarose gel and stored at $-20^{\circ} \mathrm{C}$.

\section{PCR conditions and agarose gel electrophoresis studies}

PCR studies were conducted on $418 \mathrm{~F}_{2}$ generation tomato lines for FORL and TYLCV resistant.

In the study, FORL resistance was determined with UBC194 RAPD (Fazio et al., 1999) and SCAR Frl (Mutlu et al., 2015) primers. In the study, PCR studies were conducted on tomato lines resistant to all three agents (FORL + TY1 + TY3) based on the new publication of SCAR Frl primer (Table 1). PCR reaction (final volume $25 \mu \mathrm{L}$ ) for FORL and TYLCV was conducted with $11 \mu \mathrm{L}$ DreamTaq Green PCR Master Mix 
(ThermoScientific-K1082) (containing $0.5 \mathrm{mM}$ Taq polymerase (2 U), 2X DreamTaq Green buffer, $0.4 \mathrm{mM}(200 \mu \mathrm{M})$ of dATP, dCTP, dGTP and dTTP each and and $4 \mathrm{mM}$ $\left.\mathrm{MgCl}_{2}\right), 1 \mu \mathrm{L} \mathrm{F}+1 \mu \mathrm{L}$ R primer and $1 \mu \mathrm{L}$ DNA (10 ng) and added $11 \mu \mathrm{L}$ ddH2O.

PCR conditions for the FORL-UBC194 primer were as follows: 3 min predenaturation at $95^{\circ} \mathrm{C}$, followed by 40 cycles of $1 \mathrm{~min}$ at $95^{\circ} \mathrm{C}, 1 \mathrm{~min}$ at $38^{\circ} \mathrm{C}, 1 \mathrm{~min}$ at $72^{\circ} \mathrm{C}$, and 1 cycle $10 \mathrm{~min}$ final elongation at $72^{\circ} \mathrm{C}$ min were programmed.

Table 1. Nucleotide sequences and size of the primers used for the FORL, TY3 and TY1 resistance in the experiment

\begin{tabular}{|c|c|c|c|c|}
\hline Primer & $\begin{array}{c}\text { Annealing } \\
\text { temperature } \\
\left({ }^{\circ} \mathrm{C}\right)\end{array}$ & $\begin{array}{c}\text { Primer sequence } \\
\text { (5'3') }\end{array}$ & Product size (bp) & References \\
\hline $\begin{array}{l}\text { UBC194 } \\
\text { (FORL) }\end{array}$ & 34 & 5'-AGGACGTGCC-3' & $590 \mathrm{bp}$ resistance & $\begin{array}{l}\text { Fazio et al., } \\
1999 \\
\text { Morid et al., } \\
2012 \\
\end{array}$ \\
\hline $\begin{array}{l}\text { SCAR }_{\text {Frl }} \\
\text { (FORL) }\end{array}$ & 53 & 5'-CACATTCATCATCTGTTTTTAGTCTATTC3' & $\begin{array}{c}950 \mathrm{bp} \\
\text { susceptible } \\
1000 \mathrm{bp} \\
\text { resistance } \\
950-100 \mathrm{bp} \\
\text { heterozygous } \\
\text { resistance }\end{array}$ & $\begin{array}{l}\text { Mutlu et al., } \\
2015\end{array}$ \\
\hline $\begin{array}{c}\text { P6-25-F2 } \\
\text { (TY3) }\end{array}$ & \multirow{2}{*}{53} & 5'GGTAGT GGA AAT GAT GCT GCT C-3' & \multirow{2}{*}{$\begin{array}{c}320 \mathrm{bp} \\
\text { susceptible } \\
650 \text { bp resistance }\end{array}$} & \multirow{2}{*}{$\begin{array}{c}\text { Jensen et al., } \\
2007 \\
\text { Ji et al., } \\
2007 \mathrm{abc} \\
\end{array}$} \\
\hline $\begin{array}{c}\text { P6-25-R5 } \\
\text { (TY3) }\end{array}$ & & 5'-GCTCTGCCTATTGTCCCATATATAACC-3' & & \\
\hline JB1F (TY1) & \multirow{2}{*}{55} & 5'-AACCATTATCCGGTTCACTC-3' & \multirow{2}{*}{$\begin{array}{c}400 \mathrm{bp} \\
\text { susceptible } \\
450 \mathrm{bp} \text { resistance }\end{array}$} & \multirow{2}{*}{$\begin{array}{l}\text { Castro et al., } \\
2007\end{array}$} \\
\hline JB1R (TY1) & & 5'-TTTCCATTCCTTGTTTCTCTG-3' & & \\
\hline
\end{tabular}

PCR conditions for the FORL-SCAR Frl, TY3 and TYl primers were as follows: 3 min pre-denaturation at $95^{\circ} \mathrm{C}$, followed by 35 cycles of $30 \mathrm{sec}$ at $95^{\circ} \mathrm{C}, 45 \mathrm{sec}$ at $53^{\circ} \mathrm{C}$, $45 \mathrm{sec}$ at $72^{\circ} \mathrm{C}$ and 1 final elongation cycle at $72^{\circ} \mathrm{C}$ for $10 \mathrm{~min}$ were programmed. The PCR products obtained for TY1 were cut with TaqI restriction enzyme to determine their resistance. Digestion was conducted according to Thermo Scientific. Restrictions of $10 \mu \mathrm{l}$ of the amplified products, $\mathrm{ddH}_{2} \mathrm{O} \mu 1$ 17, $10 \times$ Fast Digest Green Buffer $2 \mu 1$ and FastDigestenzyme $1 \mu \mathrm{L}$ were conducted at $37^{\circ} \mathrm{C}$ in a total volume of $30 \mu \mathrm{l}$ with $10 \mathrm{U} /$ $\mu 1$.

A GeneAmp 9700 thermocycler (Eppendorf) was used for all PCR amplifications. Digestion products were analyzed with agarose gel electrophoresis (2\% agarose w/v with TBE 1buffer) and visualized by ethidium bromide staining, and the results were recorded.

\section{Classical testing for FORL and TYLCV Pathogenicity}

Classical testing were conducted on three genotypes (B26, B40, B178) from BATEM and four genotypes (A-31, A-41, A-48 A-66) from private sector were containing the 3 target resistant genes (FORL + TY1 + TY3). 


\section{Isolate, material supply and storage}

The FORL isolate was obtained from Mersin greenhouse tomato plants and it was determined that it was a molecular (PCR) FORL isolate with high virulence, and the study was conducted with the FORL isolate coded Tarsus-0 (Tarsus / Mersin isolate) and stored at $-20^{\circ} \mathrm{C}$ (Figure 1) (Colak and Bicici, 2011).
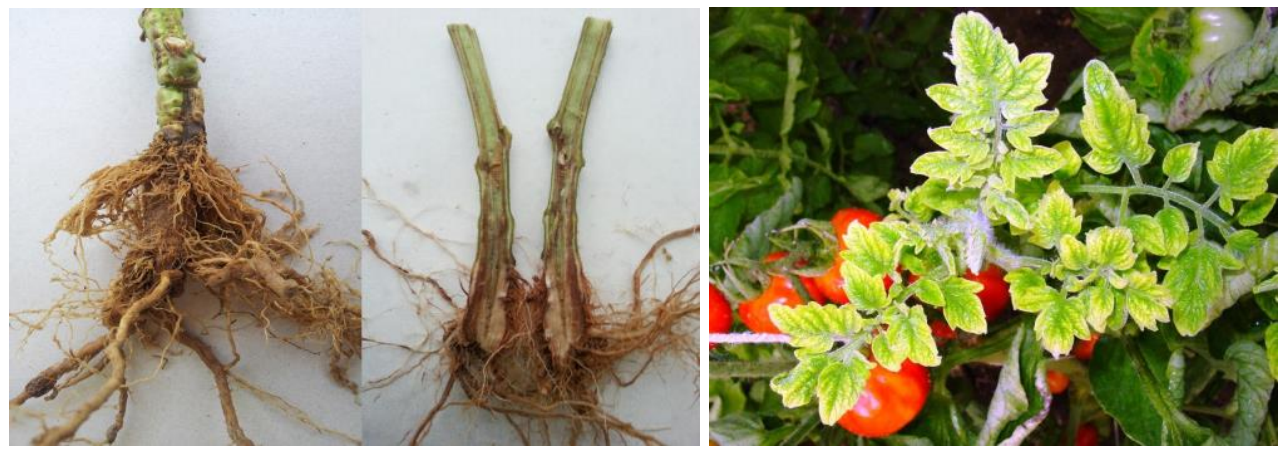

Figure 1. FORL and TYLCV symptoms in tomato plants

In the TYLCV tests; the isolate containing all three TYLCV strains obtained from Mersin greenhouse tomato fields was used as an inoculum source (Figure 1) (Fidan et al., 2011). Vector whiteflies (Bemisia tabaci) were procured from the collection regularly produced in Adana Biological Control Research Institute Directorate (BMAE).

\section{Classical testing for FORL resistance}

The FORL isolate was developed for 7 days in PDA and inoculated to $250 \mathrm{~mL}$ medium that contained $100 \mathrm{~mL}$ of PDB (Potato Dextrose Broth) and incubated for 10 days. Seedling root immersion method was used for FORL inoculation. For this purpose, the soil on 3-4 weeks old tomato seedlings were washed out, the roots were shaved and inoculated by immersion into $1 \times 10^{6}$ spores/ml FORL spore suspension for 4-5 min (Colak and Bicici, 2011). Then, the experiment was set up by planting 3 tomato seedlings from each FORL-inoculated tomato line in 5-replicates into pots $(15 \times 15 \mathrm{~cm})$ that contained sterilized peat:perlite (1:1). Experiments were set up based on random lots experimental design. The control plants were planted after immersion into sterile water. The genetic resistance to FORL disease is controlled by a single ( $F r l$ gene) dominant gene (Roberts et al., 2001). Thus, in FORL resistance tests, to determine the resistance of the lines, the plants were rooted, and the roots and vascular structures were examined, and the presence of the disease was recorded. The evaluation was conducted by observing the symptoms in the plants and browning on roots and root crowns and the scoring was conducted with a 0 - 4 scale, and resistant (0: symptom-free plants, no disease) and sensitive ( $>1$ : plants indicating symptoms, disease is present) plants were determined (Vakalounakis et al., 1997; Morid et al., 2012).

\section{Classical testing for TYLCV resistance}

Vector whiteflies (Bemisia tabaci) were used to infect the tomato plants in the experiment. In the cage studies, tomato plants infected with all three strains (TYLCV Israel, Mild and Sardinia strains) were used (Fidan et al., 2011). In the study, after the 
actual second leaf stage of the plants in the cages, 30 whiteflies per plant were released to the cages. After the whiteflies fed for 48 hours after the release, the whiteflies were terminated using an insecticide. During infection, the suction damage to the plants was prevented. For this purpose, 20 pots with $20 \mathrm{~cm}$ diameter containing peat:perlite $(1: 1)$ were placed in the cages $(80 \times 100 \times 160 \mathrm{~cm})$, and the experiment was set up with 4 pots per line and 3 plants per pot based on the random lots experimental design. Observations were conducted when the symptoms were obvious on the plants $15-21$ days after the experiment was set up and maintained for 3 weeks. The plants with disease symptoms were considered sensitive and those without symptoms were considered resistant in the experiment (Lapidot and Friedman, 2002).

All classic test experiments for FORL and TYLCV were conducted at of $26 \pm 2{ }^{\circ} \mathrm{C}$ temperatures, $60-70 \%$ relative humidity, 16 hours light -8 hours dark conditions in a climate chamber at BMAE.

\section{Greenhouse Experiments and Determination of Fruit Quality Properties}

FORL and TYLCV resistant tomato genotype seedlings were grown in the greenhouses of institutions that possessed both resistant lines. The seedlings were planted in the greenhouse with $80 \mathrm{~cm}$ inter-row and $50 \mathrm{~cm}$ intra-row distances $(2500$ plants/da) on March 2, 2016 (BATEM) and February 24, 2016 (AYER). All basic maintenance procedures were conducted regularly throughout the experiment (Günay, 2005).

In the study, harvested tomato fruit mean weight (g/fruit/FMW), mean yield per plant $(\mathrm{g} / \mathrm{plant} / \mathrm{MYP})$, total yield $(\mathrm{kg} / \mathrm{da} / \mathrm{TY})$ and certain fruit quality measures were obtained after the initial harvest. In the greenhouses in both institutions, 10 fruits were randomly selected from each line and each lot in the third tomato harvest and fruit quality properties [fruit diameter ( $\mathrm{mm} / \mathrm{FD})$ and height $(\mathrm{mm} / \mathrm{FH})$, fruit water soluble dry matter (\% / WSDM), fruit titratable acidity (\% / TA), vitamin C (L - Ascorbic Acid) content (mg / 100g / CV), pH of fruit juice, fruit juice EC measurement (ms / cm)] were determined (Guillén et al., 2006; Cemeroğlu, 2007). Fruit diameter (mm / FD): The diameter was measured at the equatorial region of the tomato fruit by using the digital caliper (Miyutoyo 500-181-30). Fruit height (mm / FH): The longitudinal section of the tomato fruit was measured by the digital caliper (Miyutoyo 500-181-30) for fruit height. Fruit water soluble dry matter (\% / WSDM): The few drops of extracted tomato juice was measured by a hand refractometer (Atago, Tokyo, Japan) for WSDM. Fruit titratable acidity (\% / TA): Titratable acidity was determined by titration of $5 \mathrm{ml}$ tomato juice with $0.1 \mathrm{~N}$ sodium hydroxide to an endpoint of $\mathrm{pH} 8.1$, results are presented as \% citric acid. Vitamin C (L - Ascorbic Acid) content (mg / 100g / CV): For ascorbic acid content, tomatoes were ground with a warring blender and $5 \mathrm{~g}$ sample was mixed with $45 \mathrm{ml} 0.4 \%$ oxalic acid and then filtered. One $\mathrm{ml}$ filtrate and $9 \mathrm{ml} \mathrm{2,6-}$ Dichlorophenolindophenol sodium salt solution $\left(\mathrm{C}_{12} \mathrm{H}_{6} \mathrm{Cl}_{2} \mathrm{NO}_{2}-\mathrm{Na}\right)$ mixed and then transmittance values $520 \mathrm{~nm}$ in a spectrophotometer (Perkin Elmer, Lambada 850 UV/Vis). Results are expressed as mg $100 \mathrm{~g}^{-1}$ (Ozdemir and Dundar, 2006). $\mathrm{pH}$ of fruit juice: The $\mathrm{pH}$ of the tomato juice was measured with WTW $315 \mathrm{i}$ model $\mathrm{pH}$ meter. Fruit juice EC measurement $(\mathrm{ms} / \mathrm{cm})$ : The EC of the tomato juice was measured with WTW $315 \mathrm{i}$ model EC meter. At the end of the experiment, whether there were differences between the tomato genotypes based on the examined properties was determined with variance analysis of the obtained data using Jump software and the comparison of the means were conducted with LSD test. 


\section{Results}

\section{Determination of FORL and TYLCV resistance of tomato genotypes with molecular studies}

PCR optimizations were conducted with FORL and TYLCV resistant and sensitive controls to determine the resistance of 418 tomato line samples that constituted the study material (Figures 2 and 3). The PCR study conducted on 196 pure tomato lines developed by BATEM breeding department with UBC 194 primer used in FORL resistance demonstrated that 60 tomato genotypes were found FORL resistant (Figure 2). Again, PCRs conducted with TY3 allele used for TYLCV resistance on the same samples demonstrated that 34 out of 196 samples were resistant of TY3. It was determined that 25 samples were resistant to TYLCV as a result of the PCR conducted with TY1 locus primers that are effective on TYLCV resistance. It was determined that 3 tomato lines coded B26, B40 and B178 were resistant to FORL and both strains of TYLCV (FORL + TY1 + TY3).

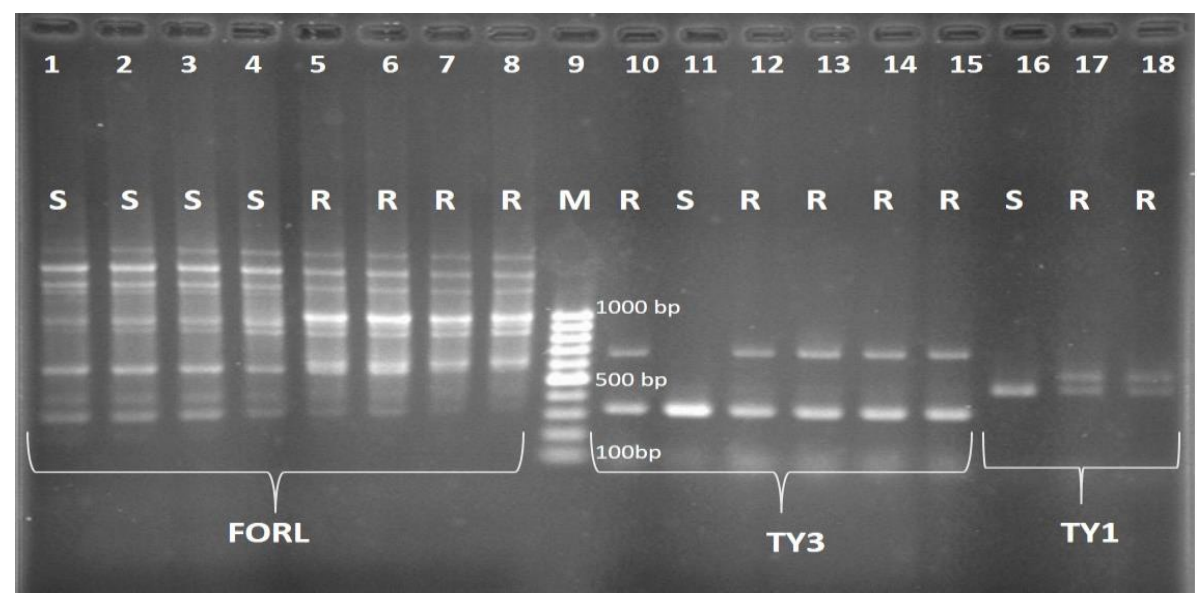

Figure 2. PCR gel image with resistance and sensitive controls for FORL and TYLCV. 1,2,3 and 4; Hazera 5656 to FORL sensitive (S) 5 and 6; FORL resistance (R) Fla.7781 genotype (590 bp) 7 and 8; Tayfun $F 1$ tomato variety to FORL resistance (590 bp double fragment) 9 ; Thermo DNA ladder (100 bp), 10 and 12; Solanum chilense LA2779, 13, 14 and 15; Tayfun F1 to TY3 resistance (320 and $650 \mathrm{bp}$ ) 11; Hazera 5656 to TY3 sensitive (320 bp), 17; Solanum chilense LA2779, 18; Tayfun F1 to TY1 resistance (400 and 450 bp), 16; Hazera5656 to TY1 sensitive (400 bp)

As a result of the molecular studies, it was determined that 160 pure tomato lines belonging to private sector (AYER) were resistant to FORL of 42 line, 10 lines were TY1 resistant, and 12 lines were TY3 resistant. Four tomato lines, namely A31, A41, A48 and A66, were identified as resistant to all three (FORL + TY1 + TY3) among the 160 pure tomato lines belonging to AYER. It was determined that none of the 62 tomato line genotypes belong to Çukurova University were resistant to any of the three resistance resources. A total of 7 tomato lines were identified as resistant to both diseases (FORL + TY1 + TY3) as a result of the conducted PCR study at FORL resistance developed by Mutlu et al. (2015) with SCAR $_{\text {Frl }}$ confirming the findings by Mutlu et al. 2015 (Figures 3 and 4). It was suggested that this new primer, used in resistant lines and confirmed with classical testing in the present study, was efficient in determination of FORL resistance and could safely be used in future breeding studies. 


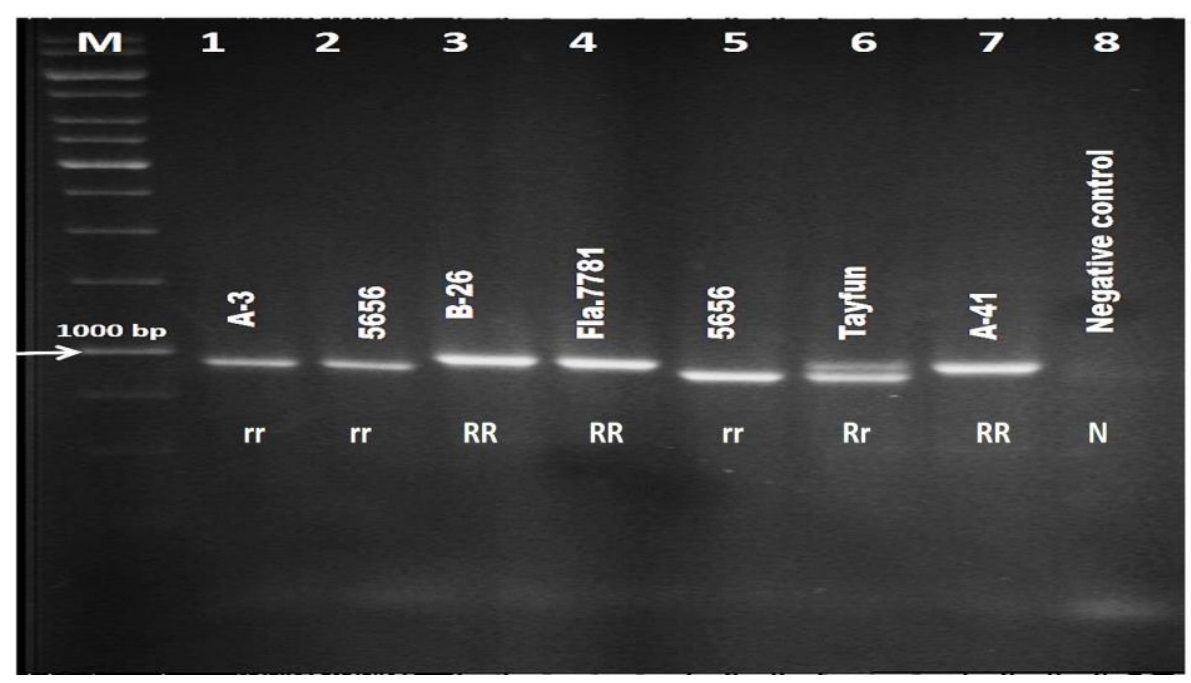

Figure 3. Agarose gel image of $S C A R_{F r l}$ primer with resistance and sensitive controls. Thermo DNA ladder (100bp), 1; A-3 tomato genotype belong to AYER, 2; Hazera 5656 to FORL sensitive (950 bp), 3; FORL resistance line B-26 tomato genotype belong to BATEM, 4; FORL resistance Fla.7781 genotype (1000 bp), 5; Hazera 5656 to FORL sensitive (950 bp), 6; FORL resistance to Tayfun F1 (950-1000 bp double fragment), 7; FORL resistance line A-41 tomato genotype belong to AYER, 8 ; Negative Control (N)

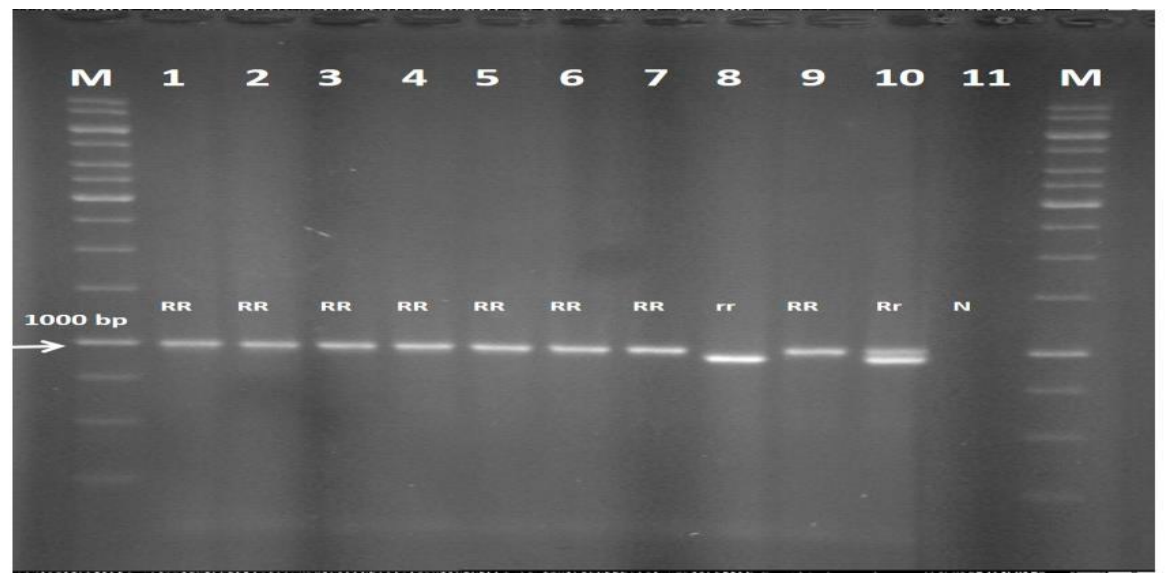

Figure 4. A gel image showing the resistance status of the seven tomato lines identified as resistant to three diseases $(F O R L+T Y 1+T Y 3)$ using the $S C A R_{F r l}$ primer in the study. Thermo DNA ladder (100bp), 1,2,3; B-26, B-40 and B-178 tomato genotypes belong to BATEM (1000 bp); 4,5,6,7; A-31, A-41, A-48 and A-66 tomato genotypes belong to AYER (1000 bp), 8; Hazera 5656 to FORL sensitive (950 bp), 9; 4; to Fla.7781 genotype to FORL resistance (1000 bp),10;

Tayfun F1 to FORL resistance (950-1000 bp double fragment), 11; Negative Control (N)

\section{Classical testing results for FORL and TYLCV resistance}

In classical testing for FORL resistance, the two-repeat experiments were set up with B26, B40 and B178 tomato genotypes from BATEM Institute and A31, A41, A48 and A66 tomato genotypes from AYER in BMAE controlled climate rooms. The experiments were terminated after 20 days, when foliage wilting and turgor loss, slowed growth, marked blackening and deaths in the root and root crown were observed as a result of FORL agent inoculation in the control plants (Hazera 5656 / FORL sensitive). 
It was determined that there were no symptoms of FORL induced crown and rot-root disease in all tomato genotypes in the experiment group as a result of the plant and root assessments (Figure 5).
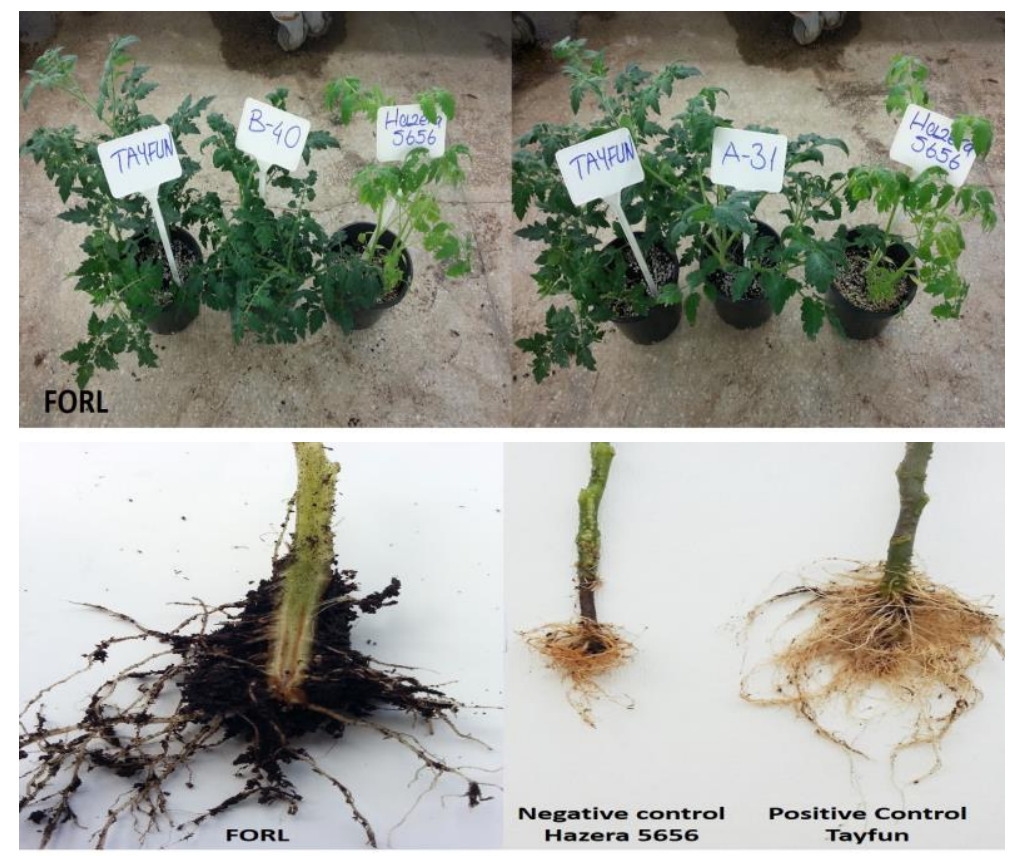

Figure 5. Classical test study of A-31 and B-40 genotypes from resistant tomato lines of FORL disease

In classical TYLCV resistance testing studies; whiteflies fed on the plants infected with three TYLCV strains were collected with infusion tube after 2 days and released onto the tomato genotypes. TYLCV-specific symptoms such as yellowing on leaf edges and shrinkage of leaves, contraction in the leaves were observed and the leaves curled upwards starting from the margins on the $16-18^{\text {th }}$ day of the experiment in sensitive control Hazera 5656 plants planted in addition to resistant line and varieties in each cage (Figure 6). The 7 tomato lines belonging to AYER and BATEM that were determined as TYLCV-resistant in molecular studies did not exhibit symptoms in classical testing cage study conducted with whitefly inoculation, thus both findings were confirmed. The use of molecular markers in development of disease resistance provides great advantages in terms of time, cost and reliability (Agrama and Scott, 2006; Anbinder et al., 2009; Ji et al., 2009). It is not possible to test hundreds of lines accurately and reliably with classical methods or to determine the inheritance of resistance (heterozygote or homozygote resistance).

In classical testing of resistant genotypes, breeders determine TYLCV resistance as the natural infection occurs in the fields for non-mechanical vector TYLCV. If molecular marker selection is not implemented in this viral disease with the sole vector of whiteflies, it is not always possible to wait for the natural infections through whiteflies in the field, and then conduct the analysis and it is not an accurate and reliable method (Verlaan et al., 2013). Because, it is not possible to understand whether the plants that appear resistant were exposed to the viral infection or whether they were infected by the whiteflies, but do not exhibit symptoms due to their resistance. 
Furthermore, it is not possible to set up experiments with whiteflies for hundreds of breeding lines. In the present study, the use of molecular markers reduced the number of genotypes from 418 to 7 tomato genotypes (B26, B40, B178, A31, A41, A48 and A66) that were resistant to all three factors (FORL+TY1+TY3), making it easier and more economic to verify these findings with classical tests. Although molecular markers provide a great advantage in terms of speed and cost, classic validation tests should be performed (Lee et al., 2015). This is due to the fact that it is important to perform classical validation tests (smyptomatologic) in determination of MAS-selective resistance, which taking the distances between the developed markers and the gene and human and marker-based errors into consideration (Caro et al., 2015; Scott et al., 2015).

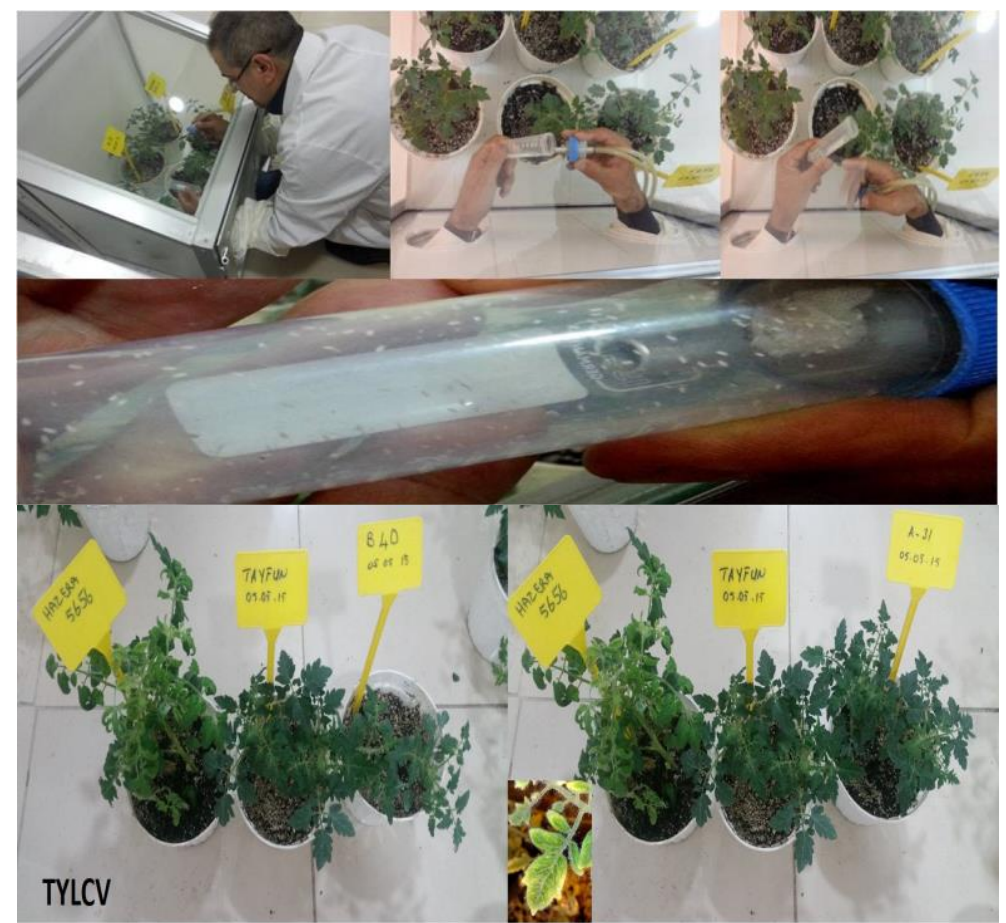

Figure 6. The release of white flies collected on TYLCV infected plants in special cages for tomato lines taken to the TYLCV resistance test and classical test study of A-31 and B-40 genotypes from resistant tomato lines of TYLCV disease

\section{Determination of the yield and certain fruit quality properties in disease resistant tomato genotypes}

In order to determine the yield and certain fruit quality properties of FORL and TYLCV resistant tomato genotypes, greenhouse experiments were set up in Antalya. Fruit harvest was initiated when tomato fruits ripened and turned red. Eight harvests were conducted in BATEM greenhouses and 6 harvests were conducted in AYER greenhouses. The tomato fruit yield and certain fruit quality property data throughout the cultivation season are presented in Tables 2 and 3.

The average yield values per plant (g/plant) and decare yield values $(\mathrm{kg} / \mathrm{da})$ were found to be statistically significant in 7 tomato genotypes determined to be resistant to FORL and TYLCV belonging to Ayer and BATEM. Among the tomato genotypes belonging to Ayer, the per plant yield ranged between 1101.8 and $2258.6 \mathrm{~g} / \mathrm{plant}$ and 
the per decare yield ranged between 2754.4 and $5646.6 \mathrm{~kg} / \mathrm{da}$, the per plant yield, for tomato genotypes belonging to BATEM varied between 1206 and $2922 \mathrm{~g} / \mathrm{plant}$ and per decare yield varied between 3015 and $7304.7 \mathrm{~kg} / \mathrm{da}$ (Tables 2 and 3). In previous studies on tomato yield, it was reported that genotypes might have different responses based on their locations, climate conditions, and plant nutrition (Şen et al., 2004; Ozbay and Ateş, 2015; Demirtaş et al., 2016). The highest mean fruit weight was observed in A-48 (166.07 g/fruit) genotype among the four Ayer tomato varieties. The highest mean fruit weight was obtained in B26 (163.57 g/fruit) genotype, while the lowest mean fruit weight was obtained in B178 (98.70 g/fruit) genotype among the three tomato genotypes from BATEM. Although certain findings in the greenhouse experiments were parallel to various studies, certain differences could be observed due to varieties, ecological conditions, plant nutrition, differences in irrigation and harvest ripeness periods (Özdemir and Özer, 2016).

Table 2. Yield and some fruit quality characteristics of tomato genotypes belong to AYER

\begin{tabular}{c|c|c|c|c|c|c|c|c|c|c}
\hline AYER & $\begin{array}{c}\text { MYP } \\
(\mathbf{g} / \mathbf{p l a n t})\end{array}$ & $\begin{array}{c}\text { TY } \\
(\mathbf{k g} / \mathbf{d a})\end{array}$ & $\begin{array}{c}\text { FMV } \\
(\mathbf{g} / \text { fruit })\end{array}$ & $\begin{array}{c}\text { FD } \\
(\mathbf{m m})\end{array}$ & $\begin{array}{c}\text { FH } \\
(\mathbf{m m})\end{array}$ & $\begin{array}{c}\text { WSDM } \\
(\boldsymbol{\%})\end{array}$ & $\begin{array}{c}\text { TA } \\
(\mathbf{\%})\end{array}$ & $\mathbf{p H}$ & $\begin{array}{c}\text { EC } \\
(\mathbf{m s} / \mathbf{c m})\end{array}$ & $\begin{array}{c}\text { CV } \\
(\mathbf{m g} / \mathbf{1 0 0 g})\end{array}$ \\
\hline $\mathbf{A 3 1}$ & $2258.6 \mathrm{a}$ & $5646.6 \mathrm{a}$ & $106.5 \mathrm{c}$ & $54.08 \mathrm{c}$ & $59.36 \mathrm{a}$ & $4.4 \mathrm{~b}$ & $0.46 \mathrm{a}$ & $4.6 \mathrm{c}$ & $4.5 \mathrm{a}$ & $22.54 \mathrm{a}$ \\
$\mathbf{A 4 1}$ & $1337.2 \mathrm{~b}$ & $3343.0 \mathrm{~b}$ & $129.93 \mathrm{~b}$ & $63.90 \mathrm{~b}$ & $56.17 \mathrm{~b}$ & $3.4 \mathrm{~d}$ & $0.37 \mathrm{~b}$ & $5.2 \mathrm{a}$ & $4.6 \mathrm{a}$ & $25.02 \mathrm{a}$ \\
$\mathbf{A 4 8}$ & $1101.8 \mathrm{~b}$ & $2754.4 \mathrm{~b}$ & $166.07 \mathrm{a}$ & $70.49 \mathrm{a}$ & $59.47 \mathrm{a}$ & $4.7 \mathrm{a}$ & $0.24 \mathrm{~d}$ & $5.1 \mathrm{~b}$ & $4.5 \mathrm{a}$ & $23.53 \mathrm{a}$ \\
$\mathbf{A 6 6}$ & $2022.4 \mathrm{a}$ & $5055.9 \mathrm{a}$ & $98.67 \mathrm{~d}$ & $56.42 \mathrm{c}$ & $52.13 \mathrm{c}$ & $4.1 \mathrm{c}$ & $0.32 \mathrm{c}$ & $4.3 \mathrm{~d}$ & $4.5 \mathrm{a}$ & $24.03 \mathrm{a}$ \\
\hline Lsd0.05 & 327.8 & 819.7 & 5.81 & 2.72 & 1.82 & 0.13 & 0.036 & 0.133 & 0.37 & 2.52 \\
\hline
\end{tabular}

Table 3. Yield and some fruit quality characteristics of tomato genotypes belong to BATEM

\begin{tabular}{c|c|c|c|c|c|c|c|c|c|c}
\hline BATEM & $\begin{array}{c}\text { MYP } \\
(\mathbf{g} / \mathbf{p l a n t})\end{array}$ & $\begin{array}{c}\text { TY } \\
(\mathbf{k g} / \mathbf{d a})\end{array}$ & $\begin{array}{c}\text { FMV } \\
(\mathbf{g} / \mathbf{f r u i t})\end{array}$ & $\begin{array}{c}\text { FD } \\
(\mathbf{m m})\end{array}$ & $\begin{array}{c}\text { FH } \\
(\mathbf{m m})\end{array}$ & $\begin{array}{c}\text { WSDM } \\
(\boldsymbol{\%})\end{array}$ & $\begin{array}{c}\text { TA } \\
(\boldsymbol{\%})\end{array}$ & $\mathbf{p H}$ & $\begin{array}{c}\text { EC } \\
(\mathbf{m s} / \mathbf{c m})\end{array}$ & $\begin{array}{c}\text { CV } \\
(\mathbf{m g} / \mathbf{1 0 0 g})\end{array}$ \\
\hline $\mathbf{B 2 6}$ & $1206 \mathrm{c}$ & $3015.3 \mathrm{c}$ & $163.57 \mathrm{c}$ & $69.39 \mathrm{a}$ & $53.65 \mathrm{a}$ & $5.06 \mathrm{~b}$ & $0.30 \mathrm{c}$ & $4.55 \mathrm{a}$ & $4.0 \mathrm{~b}$ & $26.74 \mathrm{a}$ \\
B40 & $2922 \mathrm{a}$ & $7304.7 \mathrm{a}$ & $122.13 \mathrm{a}$ & $62.31 \mathrm{~b}$ & $50.56 \mathrm{a}$ & $5.17 \mathrm{ab}$ & $0.39 \mathrm{a}$ & $4.47 \mathrm{a}$ & $4.5 \mathrm{a}$ & $25.87 \mathrm{a}$ \\
$\mathbf{B 1 1 8}$ & $2150 \mathrm{~b}$ & $5375.3 \mathrm{~b}$ & $98.70 \mathrm{~b}$ & $56.73 \mathrm{~b}$ & $52.54 \mathrm{a}$ & $5.40 \mathrm{a}$ & $0.35 \mathrm{~b}$ & $4.50 \mathrm{a}$ & $3.9 \mathrm{~b}$ & $27.83 \mathrm{a}$ \\
\hline $\mathrm{Lsd}_{0.05}$ & 327.3 & 818.3 & 20.34 & 5.64 & 5.19 & 0.236 & 0.035 & 0.1128 & 0.1153 & 5.293 \\
\hline
\end{tabular}

The water-soluble dry matter content (WSDM) is an important quality criterion in tomato fruit, and it was determined that the highest WSDM content was in A-48 genotype with $4.7 \%$ among AYER tomato genotypes and the highest WSDM content was in B178 genotype with 5.40\% among BATEM genotypes (Table 3). It was reported that the water soluble dry matter content in tomato fruits varies between 2.9 and $5.9 \%$ (Özbay et al., 2012). The titratable acidity (\%) may vary based on the variety and ripeness period of the fruit in tomato fruit juice (Ozbay and Ateş, 2015). It was determined that the acidity rates varied between $0.46-0.24 \%$ in AYER tomato genotypes and between $0.30-0.39 \%$ in BATEM tomato genotypes.

It was found that the difference between $\mathrm{pH}$ values of AYER tomato genotypes was significant in the experiment and the highest $\mathrm{pH}$ was obtained with the A41 genotype (5.2), and the lowest $\mathrm{pH}$ was obtained with the A66 tomato genotype (4.3) (Table 2). BATEM tomato genotype $\mathrm{pH}$ values ranged between 4.47 and 4.55 (Bozköylü and Daşgan, 2010). There were no differences between the fruit quality properties of EC and 
vitamin $\mathrm{C}$ content of AYER tomato genotypes. The highest $\mathrm{EC}$ and vitamin $\mathrm{C}$ values were obtained in the A41 genotype $(4.6 \mathrm{~ms} / \mathrm{cm}-25.02 \mathrm{mg} / 100 \mathrm{mg})$. The highest EC value was obtained in the B40 genotype with $4.5 \mathrm{~ms} / \mathrm{cm}$ in among BATEM genotypes. All tested varieties exceeded the limit value of $8.4 \mathrm{mg} / 100 \mathrm{~g}$ for Vitamin $\mathrm{C}$ in tomatoes (Özbahçe and Padem, 2007).

\section{Discussion}

Using molecular markers in breeding studies, the choice of the closest of the gene in the primers used in disease resistance is important in terms of the reliability of the results. Since CAPS, SCAR and co-dominant SCAR primers, which are a further step from RAPD primers in determination of FORL resistance, were not developed or patented and published for this disease, several studies, similar to the present study, have used UBC 194 RAPD primers, which is closest to the gene, to determine FORL resistance (Fazio et al., 1999). However, the fact that the RAPD markers obtained in these studies were not reproducible, the difficulties in clear definition in agarose gel and the lack of inheritance of FORL resistance (heterozygous or homozygous) demonstrated that further studies should be conducted (Tanyolac and Akkale, 2010). For this purpose, Truong et al. (2011) developed RAPD markers and transformed these into SCAR and made these available for use in breeding experiments. Mutlu et al. (2015) developed the SCAR marker into a Co-dominant SCAR, obtaining the SCAR Frl $_{\text {marker, at a distance }}$ of $0.016 \mathrm{~cm}$ to the gene and almost on top of the $\mathrm{Frl}$ gene, and which could demonstrate whether the inheritance is heterozygous or homozygous. It was determined in the present study once more that the co-dominant SCAR $_{\text {Frl }}$ marker is reliable for determination of the heterozygous or homozygous status of inheritance in F2 and F3 populations in breeding studies, it can be accurately and easily identified in agarose gel, reduces the hybridization study costs, saves time and promotes rapid commercialization of the lines when compared to the previous FORL resistance markers.

In the study, seven genotypically resistant lines (B26, B40, B178, A31, A41, A48 and A66) against both TY1 and TY3 were infected with whiteflies to confirm the symptomatologic results of the markers in tomato plant. Infections demonstrated that primers of the genes that provide TY1 and TY3 resistance (Ty-1, JB1 and Ty-3, P6-25) could be used in resistance studies. It was reported that the TY1 gene was not very effective alone due to the presence of several TYLCV strains and controlled with a high number of genes (Zamir et al., 1994). It was reported that the TY3 marker could be used effectively in MAS since it is located on the $6^{\text {th }}$ chromosome and close to the gene $(0.3$ $\mathrm{cM}$ ), its Co-dominant SCAR characteristic, and could reflect heterozygous, homozygous resistant and sensitive genotypes concurrently with single PCR (Ji et al., 2007c). Although the TY4, TY5 and TY6 markers were developed since the development of TY3 marker, the present study confirmed that the most effective resistance was TY1 and TY3 resistance. The knowledge on the existing strains in Turkey and their resistance to the resistance markers and their effectiveness were determined and confirmed. The existence of different TYLCV strains, especially in Asia, revealed that different markers should be tested in these areas (Hutton et al., 2012). Israel and Mild strains of TYLCV are the most prevalent strains globally, and the TY1 and TY3 markers developed against these strains maintain the status of being the most used marker in breeding studies in the world (Lee et al., 2015). 


\section{Conclusion}

In today's conditions, there is a need for resistance against at least 3 and more disease agents depending on the production site and time. As the number of required resistances increases, breeding period gets longer, and it could even become impossible. Thanks to the present study findings, resistance to significant biotic factors (FORL + TYLCV) were determined, saving time for the line owner organization in commercialization of multi-resistance seven tomato variety candidates. This study showed that both disease resistant and argonomic as the market value of the highest new kind of candidate (A31 and B40) by determined by line with the institution will contribute greatly to quickly pass the commercialization and market presentation stages. In this study, multiple markers were tested for a gene, for the determination of FORL resistance, UBC-194 and SCARFr1 markers, TY1 and TY3 markers for TYLCV resistance have been confirmed. The results of the study will reveal the possibility that molecular markers used in the development of resistant lines and varieties of these diseases may be an alternative to classical testing and will shed light on future studies. Furthermore, with the determination of the parents who will be used as father or mother and resistant to one of the FORL and TYLCV disease, it became possible to design alternatives projects (F1 hybrid) to obtain new varieties based on the globally prominent fruit quality criterion requirements.

Acknowledgements. We would like to express our thanks to the Scientific and Technological Research Council of TURKEY (TÜBİTAK) for the financial support provided for this study within the scope of the project numbered $213 \mathrm{O} 103$.

\section{REFERENCES}

[1] Agrama, H. A., Scott, J. W. (2006): Quantitative trait loci for Tomato yellow leaf curl virus and Tomato mottle virus resistance in tomato. - Journal American Horticulture Science 131: 267-272.

[2] Anbinder, I., Reuveni, M., Azari, R., Paran, I., Nahon, S., Shlomo, H., Chen, L., Lapidot, M., Levin, I. (2009): Molecular dissection of Tomato leaf curl virus resistance in tomato line TY172 derived from Solanum peruvianum. - Theoretical and Applied Genetics 119: 519-530.

[3] Anfoka, G. H., Abhary, M., Nakhla, M. K. (2005): Molecular identification of species of the Tomato yellow leaf curl virus complex in Jordan. - Journal Plant Patholhology 87: 61-66.

[4] Barone, A., Ercolano, M R., Langella, R., Monti, L., Frusciante, L. (2005): Molecular marker-asisted selection for pyramiding resistance genes in tomato. - Adv. Hort. Sci. 19: 147-152.

[5] Belabess, Z., Dallot, S., El-Montaser, S., Granier, M., Majde, M., Tahiri, A., Blenzar, A., Urbino, C., Peterschmitt, M. (2015): Monitoring the dynamics of emergence of a noncanonical recombinant of Tomato yellow leaf curl virus and displacement of its parental viruses in tomato. - Virology 486: 291-306.

[6] Bozköylü, A., Daşgan, H. (2010): Sera Topraksız Domates Yetiştiriciliğinde Kimyasal Ve Organik Gübrelemenin Karşılaştırılması. - TUBAV Bilim Dergisi, cilt:3, sayı:2, sayfa: $174-181$.

[7] Caro, M., Verlaan, M. G., Julián, O., Finkers, R., Wolters, A. M., Hutton, S. F., Scott, J. W., Kormelink, R., Visser, R. G., Díez, M. J., Pérez-de-Castro, A., Bai, Y. (2015): 
Assessing the genetic variation of $T y-1$ and $T y-3$ alleles conferring resistance to tomato yellow leaf curl virus in a broad tomatogermplasm. - Molecular Breeding 35: 132.

[8] Castro, A. P., Blanca, J. M., D1'ez, M. J., Vinals, F. N. (2007): Identification of a CAPS marker tightly linked to the tomato yellow leaf curl disease resistance gene Ty-1 in tomato. - European Journal Plant Pathology 117: 347-356.

[9] Cemeroğlu, B. (2007): Gıda Analizleri. - Gıda Teknolojileri Derneği Yayınları No: 34: 52-84.

[10] Colak, A., Bicici, M. (2011): Determination Differantiating of Fusarium oxysporum formae spseciales and determination incidence, severity and prevalence of Fusarium wilt and crown - root rot in protected tomato growing areas of East Mediterranean Region of Turkey. - Plant Protection Bulten 51(4): 331-345.

[11] Çolak, A., Biçici, M. (2013): PCR detection of Fusarium oxysporum f.sp. radicislycopersici and races of $F$. oxysporum f.sp. lycopersici of tomato in protected tomato growing areas of Eastern Mediterranean Region of Turkey. - Turk1sh Journal of Agriculture and Foresty 37(4): 457-467.

[12] Czosnek, H. (2007): Tomato Yellow Leaf Curl Virus Disease. - Springer book, p:448. $85-118$

[13] Darling, D. C., Brickell, P. M. (1994): Nucleic Acid Blotting (The basics). - Oxford University Press Inc., New York, p:111.

[14] Demirtaş, E. I., Arı, N., Özkan, C. F., Öktüren, A. F. (2016): Determination of Residual Effect of Urban Solid Waste Compost on Tomato Grown under Green House Condition. - Derim journal 33(1): 144-158.

[15] Devran, Z., Kahveci, E., Hong, Y., Studholme, D. J., Tör, M. (2018): Identifying molecular markers suitable for $\mathrm{Frl}$ selection in tomato breeding. - Theoretical and Applied Genetics. https://doi.org/10.1007/s00122-018-3136-0.

[16] Fazio, G., Stevens, M., Scott, J. W. (1999): Identification of RAPD markers linked to fusarium crown and root rot resistance $(F r l)$ in tomato. - Euphytica 105: 205-210.

[17] Fidan, H., Karacaoglu, M., Çaglar, B. K., Koç, G., Satar, G. (2011): Domates Sarı Yaprak Kıvırcıklık Virüsü (Tomato Yellow Leaf Curl Virus (TYLCV)). - Irklarının Ve Vektör Bemisia Tabaci (Hemiptera Aleyrodidae) Biotype-ilişkisinin Belirlenmesi. Türkiye IV. Bitki Koruma Kongresi Bildirileri 28-30 Haziran 2011, Kahramanmaraş, s.406.

[18] Guillén, F., Castillo, S., Zapata, P. J., Martinez-Romero, D., Serrano, M., Valero, D. (2007): Efficacy of 1-MCP Treatment in Tomato Fruit 2.Effect of Cultivar and Ripening Stage at Harvest. - Postharvest Biology and Technology 42: 235-242.

[19] Günay, A. (2005): Özel Sebze Yetiştiriciliği II. - Bölüm, Domates yetiştiriciliğii, 318-343.

[20] Hibar, K. (2002): La fusariose du collet et des racines de la tomate: Pathoge'nicite'et moyens de lutte. - Me'moire de Diplo^me d'Etudes Approfondies en Protection des Plantes et Environnement. - Tunisie, Ecole Supe' rieure d'Horticulture et d'Elevage de Chott Mariem, 54 pp.

[21] Hutton, S. F., Scott, J. W., Schuster, D. J. (2012): Recessive resistance to tomato yellow leaf curl virus from the tomato cultivar Tyking is located in the same region as Ty-5 on chromosome 4. - HortScience 47(3): 324-327.

[22] Jensen, K. S., Betteray, B., Smeets, J., Yuanfu, J., Scott, J. W., Mejía, L., Havey, M. J., Maxwell, D. P. (2007): Co-dominant SCAR Marker, P6-25, for Detection of the ty-3, Ty3 , and $T y-3 a$ alleles of Chromosome 6 of Tomato. - College of Agricultural and Life Sciences at University of Wisconsin-Madison, and by grants from Unilever Bestfoods Ltd. and the Florida Tomato Committee to J. W. Scott.,p: 25.

[23] Ji, Y., Schuster, D. J., Scott, J. W. (2007a): Ty-3, a begomovirus resistance locus near the tomato yellow leaf curl virüs resistance locus Ty-1 on chromosome 6 of tomato. Molecular Breeding 20: 271-284.

[24] Ji, Y., Scott, J. W., Hanson, P., Graham, E., Maxwell, D. P. (2007b): Sources of resistance, inheritance, and location of genetic loci conferring resistance to members of the tomato-infecting begomoviruses. - In: Czosnek, H. (ed.) Tomato yellow leaf curl 
virus disease: Management, molecular biology, breeding for resistance. Kluwer, Dordrecht, The Netherlands, pp. 343-362.

[25] Ji, Y., Salus, M. S., Van Betteray, B., Smeets, J., Jensen, K., Martin, C. T., Mejía, L., Scott, J. W., Havey, M. J., Maxwell, D. P. (2007c): Co-dominant SCAR markers for detection of the Ty-3 and Ty-3a loci from Solanum chilense at $25 \mathrm{cM}$ of chromosome 6 of tomato. - Rept. Tomato Genetic Cooperative. 57: 25-28.

[26] Ji, Y., Scott, J. W., Schuster, D. J. (2009): Toward fine mapping of the tomato yellow leaf curl virus resistance gene Ty-2 on chromosome 11 of tomato. - HortScience 44(3): 614618.

[27] Kabaş, A., İlbi, H., Mutlu, N., Ünlü, A. (2012): Inheritance of Resistance To Fusarium oxysporum f.sp. radicis lycopersici Caused Root Disease In Tomato. - Bati Akdeniz Agriculture Research Institute, Derim Journal 29(1): 1-8.

[28] Lapidot, M., Friedman, M. (2002): Breeding for resistance to whitefly transmitted geminiviruses. - Annals Applied Biology 140: 109-127.

[29] Lee, H. J, Kim, B. Y., Bae, C., Kang, W. H., Kang, B. C., Yeam, I., Oh, C. S. (2015): Development of a single-nucleotide polymorphism marker in the $S w-5 b$ gene conferring disease resistance to Tomato spotted wilt virus in tomato. - Korean Journal of Horticultural Science and Technology 33(5): 730-736.

[30] Mabvakure, B., Martin, D. P., Kraberger, S., Cloete, L., van Brunschot, S., Geering, A. D. W., Thomas, J. E., Bananej, K., Lett, J. M., Lefeuvre, P., Varsani, A., Harskins, G. W. (2016): Ongoing geographical spread of Tomato yellow leaf curl virus. - Virology 498: 257-264.

[31] Morid, B., Hajmansoor, S., Kakvan, N. (2012): Screening of resistance genes to fusarium root rot and fusarium wilt diseases in tomato (Lycopersicon esculentum) cultivars using RAPD and CAPs markers. - European Journal of Experimental Biology 2(4): 931-939.

[32] Moriones, E., Navas-Castillo, J. (2000): Tomato yellow leaf curl virus, an emerging virus complex causing epidemics worldwide. - Virus Res. 71: 123-134.

[33] Mutlu, N., Demirelli, A., Ibli, H., Ikten, C. (2015): Development of co-dominant SCAR markers linked to resistant gene against the Fusarium oxysporum f. sp. radicis-lycopersici. - Theoretical and Applied Genetics. DOI 10.1007/s00122-015-25474.

[34] Ozbay, N., Newman, S. E., Brown, W. M. (2004): Evaluation of Trichoderma harzianum strains to control crown and root rot of greenhouse fresh market tomatoes. - Proc. XXVI IHC- Managing Soil-Borne Pathogens, Vanachter, A. (ed.), Acta Horticulture 635, ISHS 2004: 79-85.

[35] Ozbay, N., Ateş, K. (2015): Evaluation of Fresh Market Tomato Cultivars for Climatic Conditions of Bingöl. - Turkish Journal Of Agricultural and Natural Sciencese 2(2): 226236.

[36] Ozdemir, A., Dundar, E. O. (2006): The effects of fungicide and hot water treatments on the internal quality parameters of Valencia oranges. - Asian Journal Plant. Science 5: $142-146$

[37] Özbahçe, A., Padem, H. (2007): The Determination of Some Processing Tomato Varieties Having Suitable Superior Yield and Technological Properties in Isparta Ecological Conditions. - Süleyman Demirel Üniversitesi, Fen Bilimleri Enstitüsü Dergisi, (11-2): 28-133.

[38] Özbay, N., Sarıyer, T., Korkmaz, A. (2012): Afyonkarahisar İli Ekolojik Şartlarına Uygun Sofralık Domates Çeşitlerinin Belirlenmesi. - Doğa ve Fen Dergisi. 1(2): 64-70.

[39] Özdemir, A., Özer, H. (2016): Effect of Different Doses of Fertilizer on Yield and Quality of Organically Grown Tomato. - Süleyman Demirel Üniversitesi Ziraat Fakültesi Dergisi 11(1): 17-26.

[40] Roberts, P. D., McGovern, R. J., Datnoff, L. E. (2001): Fusarium crown and root rot of tomato in Florida. - University of Florida, IFAS Extension, pp.52. 
[41] Sabir, F. K., Kusvuran, Ş., Dasgan, H. Y. (2012): Effects of 1-Methylcycloprpene treatment on postharvest life and quality in four tomatoes cultivars. - The Journal of Animal \& Plant Sciences 22(4): 1086-1091.

[42] Scott, J. W. (2005): Perspective on Tomato Disease Resistance Breedig: Past, Present and Future. - Acta Horticulture 695.

[43] Scott, J. W., Hutton, S. F., Freeman, J. H. (2015): Fla. 8638B and Fla. 8624 Tomato Breeding Lines with Begomovirus Resistance Genes ty-5 Plus Ty-6 and Ty-6, respectively. - HortScience 50: 1405-1407.

[44] Şen, F., Uğur, A., Bozokalfa, M. K., Eşiyok, D., Boztok, K. (2004): Bazı Sera Domates Çeşitlerinin Verim Kalite ve Depolama Özelliklerinin Belirlenmesi. - Ege Üniv. Ziraat Fakültesi Dergisi 41(2): 9-17.

[45] Tanyolac, B., Akkale, C. (2010): Screening of resistance genes to fusarium root rot and fusarium wilt diseases in $\mathrm{F}_{3}$ family lines of tomato (Lycopersicon esculentum) using RAPD and CAPs markers. - African Journal of Biotechnology 9: 2727-2730.

[46] Torre, C., Donaire, L. Gómez-Aix, C., Juárez, M., Peterschmitt, M., Urbino, C., Hernando, Y., Agüero, J., Aranda, M. A. (2018): Characterization of Begomoviruses Sampled during Severe Epidemics in Tomato Cultivars Carrying the Ty-1 Gene. - Int. J. Mol. Sci 19: 2614.

[47] Truong, H. T. H., Choi, H., Cho, M. C., Lee, H. E. (2011): Conversion of the random amplified polymorphic DNA (RAPD) marker UBC\#116 linked to Fusarium crown and root rot resistance gene $(\mathrm{Frl})$ into a co-dominant sequence characterized amplified region (SCAR) marker for marker-assisted selection of tomato. - African Journal of Biotechnology 10: 1130-1136.

[48] Vakalounakis, D. J., Laterrot, H., Moretti, A., Ligoxıgakis, E. K., Smardas, K. (1997): Linkage between $\mathrm{Frl}$ (Fusarium oxysporium f. sp. radicis-lycopersici resistance) and Tm2 (Tobacco mosaic virus resistance-2) loci in tomato (Lycopersicon esculentum). Annals Applied Biology 130: 319-323.

[49] Verlaan, M. G., Hutton, S. F., Ibrahem, R. M., Kormelink, R., Visser, R. G. F., Scott, J. W., Edwards, J. D., Bai, Y. (2013): The Tomato yellow leaf curl virus resistance genes $T y-1$ and $T y-3$ are allelic and code for DFDGD-class RNA-dependent RNA polymerases. - PLoS Genetics 9(3):e1003399.

[50] Yan, G., Liu, H., Wang, H., Lu, Z., Wang, Y., Mullan, D., Hamblin, J., Liu, C. (2017): Accelerated generation of selfed pure line plants for gene identification and crop breeding. - Front Plant Sci 8:1786. https ://doi.org/10.3389/fpls.2017.01786.

[51] Zamir, D., Ekstein-Michelson, I., Zakay, Y., Navot, N., Zeidan, M., Sarfatti, M., Eshed, Y., Harel, E., Pleban, T., Vanoss, H., Kedar, N., Rabinowitch, H. D., Czosnek, H. (1994): Mapping and introgression of a tomato yellow leaf curl virus tolerance gene, Ty-1. Theoretical and Applied Genetics 88: 141-146. 